\title{
Serum leptin levels in hypo- and hyperthyroidism
}

\author{
U Leonhardt, U Ritzel, G Schäfer, W Becker ${ }^{1}$ and G Ramadori \\ Department of Medicine, Division of Gastroenterology and Endocrinology and 'Department of Nuclear Medicine, University of Göttingen, Göttingen, \\ Germany \\ (Requests for offprints should be addressed to G Ramadori, Department of Medicine, Division of Gastroenterology and Endocrinology, \\ Robert Koch Strasse 40, D-37075 Göttingen, Germany)
}

\begin{abstract}
Leptin, the product of the $o b$ gene, is an important circulating signal for the regulation of body weight. In the present study the role of immunoreactive leptin (leptin-IR) was investigated in functional thyroid disease. Serum leptin-IR levels of 23 hypothyroid and 19 hyperthyroid patients were compared with 21 controls. Leptin-IR was quantified by a specific RIA. In hyperthyroid patients, leptin-IR was not different from controls. Serum leptin-IR levels were significantly increased in hypothyroid patients $(21 \cdot 0 \pm 2 \cdot 7 \mu \mathrm{g} / 1$ vs
\end{abstract}

controls $10 \cdot 8 \pm 2 \cdot 1 \mu \mathrm{g} / 1, \quad P=0 \cdot 0044)$. When serum leptin of hypothyroid patients was compared with euthyroid controls of the same body mass index the difference was still significant $(P=0.0333$ by paired Student's $t$-test). This might indicate that elevation of the serum leptin level does not merely reflect changes in body weight secondary to hypothyroidism, but might be increased to overcome the gain of body weight caused by hypothyroidism.

Journal of Endocrinology (1998) 157, 75-79

\section{Introduction}

Leptin, the protein product of the ob gene, is an important circulating signal for the regulation of body weight (Zhang et al. 1994). It interacts with specific receptors in the hypothalamus affecting appetite and satiety centres of the brain (Rohner-Jeanrenaud \& Jeanrenaud 1996). It is supposed to act as a negative feedback 'adipostatic signal' to brain centres controlling energy homeostasis and food uptake (Campfield et al. 1995, Stephens et al. 1995, Rohner-Jeanrenaud \& Jeanrenaud 1996, Rohner-Jeanrenaud et al. 1996, Wang et al. 1997). In ob/ob mice, obesity is caused by a lack of circulating leptin due to mutations in the $o b$ gene, and weight loss is achieved by leptin administration (Pelleymounter et al. 1995). In humans, sequence variations of the $o b$ gene are not the cause of increased body weight in most cases (Maffei et al. 1996, Niki et al. 1996), although ob mutations may occur in some cases of extreme human obesity (Clement et al. 1996, Reed et al. 1996).

Thyroid status affects food intake and body mass index (BMI). Body weight is often decreased in hyperthyroidism and is increased in hypothyroid patients (Ingbar 1985). Since leptin decreases food intake and increases energy expenditure, the aim of the present study was to investigate the role of serum leptin in functional thyroid disease.

\section{Methods}

\section{Patients}

Twenty-one euthyroid controls, 19 hyperthyroid and 23 hypothyroid patients were included in the study. Induced hypothyroidism was present in 13 patients with thyroid carcinoma. In 10 patients hypothyroidism was due to autoimmune disease. Hyperthyroidism was caused by Graves' disease in 8 cases and by autonomy in 11 cases (Table 1).

\section{Leptin RIA}

A synthetic fragment consisting of amino acids 126-140 (ETLDSLGGVLEASGY) of human leptin was custom synthesised (Bachem Biochemica GmbH, Heidelberg, Germany). Antibodies were raised in seven female rabbits (strain Neuseeländer, $2 \cdot 3-2 \cdot 7 \mathrm{~kg}$ ). After coupling of the fragment to albumin, initial immunisation was performed after mixing 1:1 with Complete Freund's Adjuvant, and booster injections were given at 6-week intervals with Incomplete Freund's Adjuvant. For radiolabelling, the leptin fragment was iodinated with ${ }^{125}$ I by the chloramine $\mathrm{T}$ method. Labelled fragment was purified by reversephase HPLC using a Waters $\mu$ Bondapak C18 column. RIA was set up in $500 \mu \mathrm{l}$ of a $0 \cdot 06 \mathrm{M}$ phosphate EDTA buffer with addition of sodium azide. Labelled fragment 


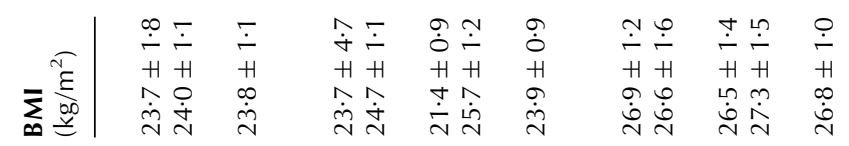

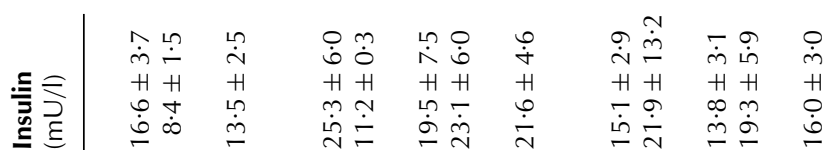

政

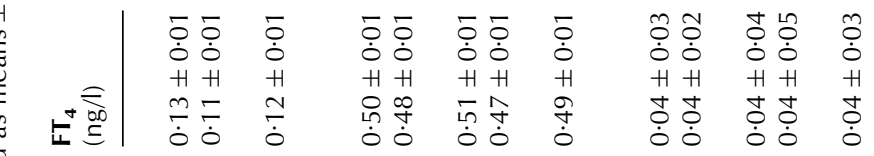

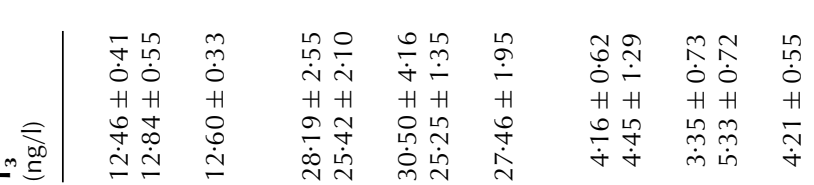

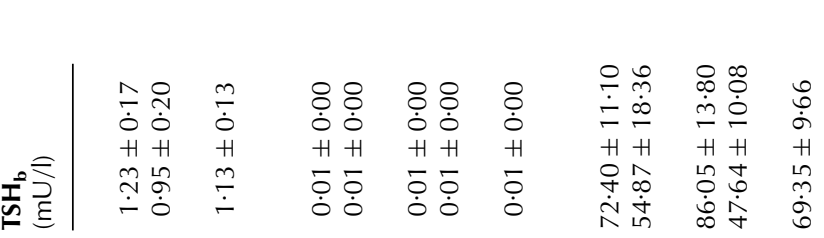

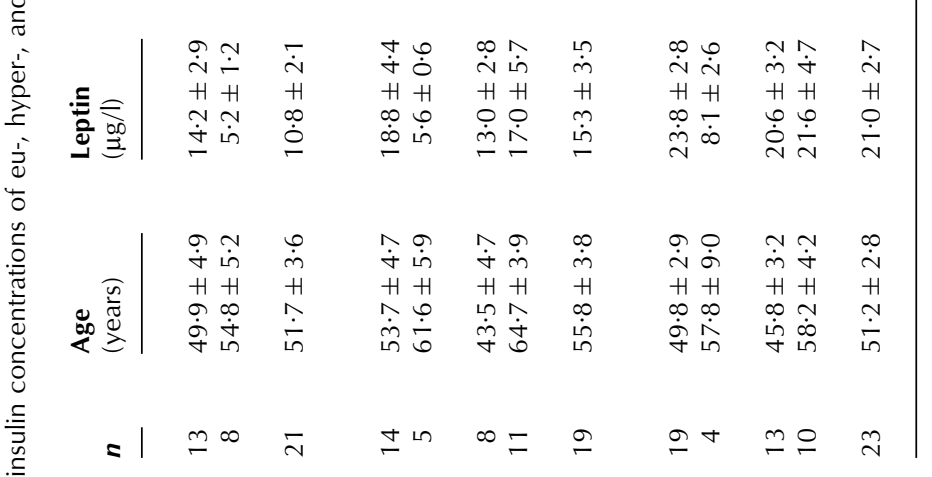

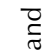

๒

के

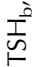

謽

$\frac{1}{2}$

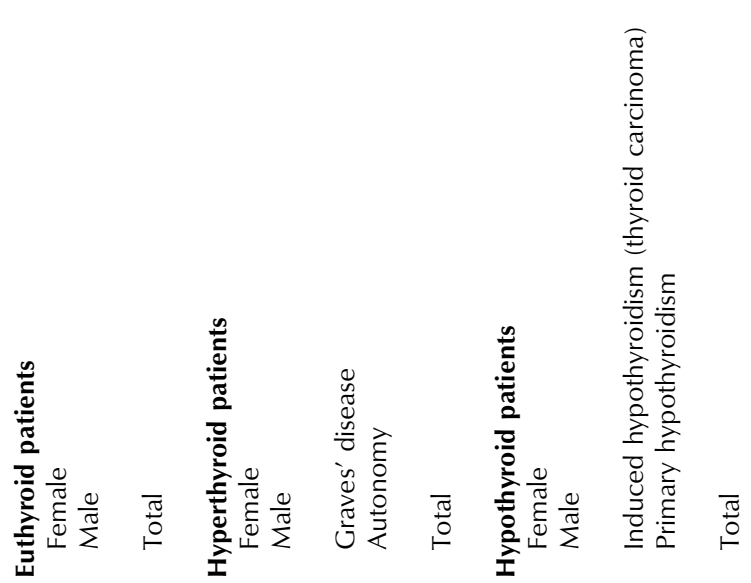


$(50 \mu \mathrm{l})$ was added, and antibody was added to all tubes except for non-specific binding tubes. Synthetic human leptin (Tebu, Frankfurt, Germany) was used as an assay standard. Bound and free antibody were separated by addition of charcoal, subsequent centrifugation and separation of supernatant and pellet. All samples were assayed in duplicate. Plasma or gel chromatography samples were measured in a single assay.

For crossreactivity studies, insulin, tri-iodothyronine $\left(\mathrm{T}_{3}\right)$, free serum thyroxine $\left(\mathrm{FT}_{4}\right)$ and thyroid-stimulating hormone (TSH) were assayed at 1, 5, 10, 50 and $100 \mathrm{nmol} /$ tube.

\section{Gel chromatography}

Gel chromatography of selected serum samples was performed on Sephadex G75 columns (length $26.5 \mathrm{~cm}$, diameter $3.5 \mathrm{~cm}) .{ }^{125} \mathrm{I}$, Blue Dextran and cytochrome C were used as markers for molecular size. Recovery was expressed as per cent of the amount of peptide found in assayed fractions related to the amount of peptide loaded onto the column.

Quantification of insulin, TSH, $\mathrm{T}_{3}$ and $\mathrm{FT}_{4}$

Blood samples were collected in Sarstedt monovetes and centrifuged immediately for $15 \mathrm{~min}$ at $4{ }^{\circ} \mathrm{C}$. Serum was aliquoted and frozen on solid carbon dioxide. Insulin was quantified using a commercial RIA (Pharmacia, Uppsala, Sweden), $\mathrm{T}_{3}$ and $\mathrm{FT}_{4}$ by competitive immunoassays (Ciba Corning Diagnostics, Fernwald, Germany) and TSH by a two-sided chemiluminometric immunoassay (Ciba Corning Diagnostics).

\section{Statistical analysis}

Data are shown as mean values \pm S.E.M. Statistical analysis was performed by an unpaired Student's $t$-test (two tailed $P$ values, 95\% confidence intervals) unless otherwise indicated.

\section{Results}

\section{Leptin RIA}

Chloramine $\mathrm{T}$ iodination of leptin fragment resulted in a ${ }^{125}$ I incorporation of $84 \cdot 3 \%$. HPLC purification showed a peak eluting at $37 \%$ acetonitrile comprising more than $90 \%$ of incorporated radioactive iodine (Fig. 1). Our antibody XC71 gave a binding of $37 \cdot 4 \%$ after incubation for 5 days. The antiserum used in the RIA at a final dilution of 1:720 000 was collected after the fourth boost. The sensitivity of the antibody was $1.5 \mathrm{fmol} /$ tube. It did

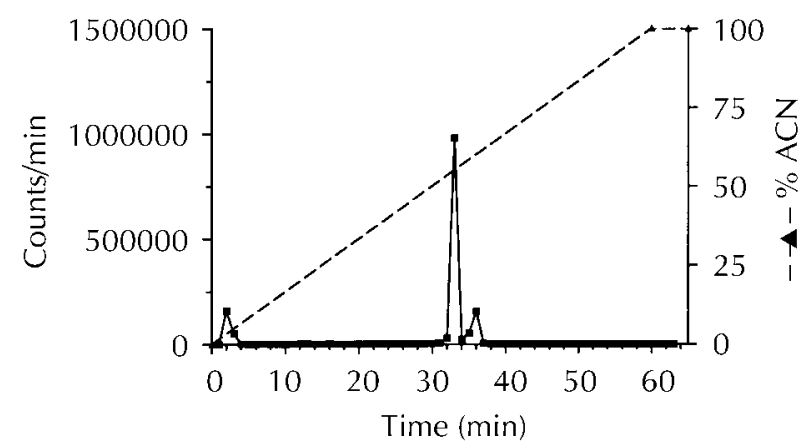

Figure 1 HPLC purification of radioiodinated leptin fragment, using a Waters HPLC system and an acetonitrile (ACN)/water gradient, showing a peak eluting at $37 \% \mathrm{ACN}$ comprising more than $90 \%$ of incorporated radioiodine.

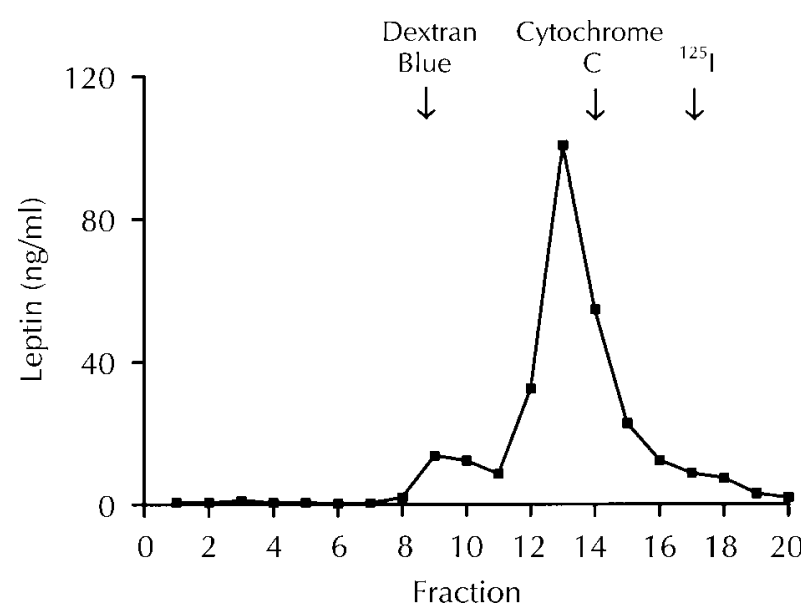

Figure 2 Gel chromatography (Sephadex G75) of a serum sample. The major peak of leptin ( $87 \%$ plasma radioactivity) eluted at the position of human leptin.

not show any crossreactivity with insulin, $\mathrm{T}_{3}, \mathrm{FT}_{4}$ or TSH up to $0 \cdot 1 \mu \mathrm{mol} /$ tube. Intra-assay variation was $4 \cdot 7 \%$, interassay variation $11 \cdot 4 \%$.

\section{Gel chromatography}

Mean recovery of pooled plasma samples was $56 \%(n=6$, range 51 to $60 \%)$. The major peak of leptin plasma radioactivity $(87 \%)$ eluted at the position of human leptin (Fig. 2). Thirteen per cent of immunoreactive leptin (leptin-IR) eluted at $2000 \mathrm{Da}$.

\section{Serum leptin-IR levels in thyroid disease}

Basal TSH $\left(\mathrm{TSH}_{\mathrm{b}}\right)$ was $1 \cdot 13 \pm 0 \cdot 13 \mathrm{mU} / 1$ (mean \pm s.E.M.) in euthyroid patients, $69 \cdot 35 \pm 9.66 \mathrm{mU} / 1$ in hypothyroid, and $0.01 \pm 0.00 \mathrm{mU} / 1$ in hyperthyroid patients. $\mathrm{T}_{3}$ levels were $12.60 \pm 0.33 \mathrm{ng} / 1$ in the euthyroid, 


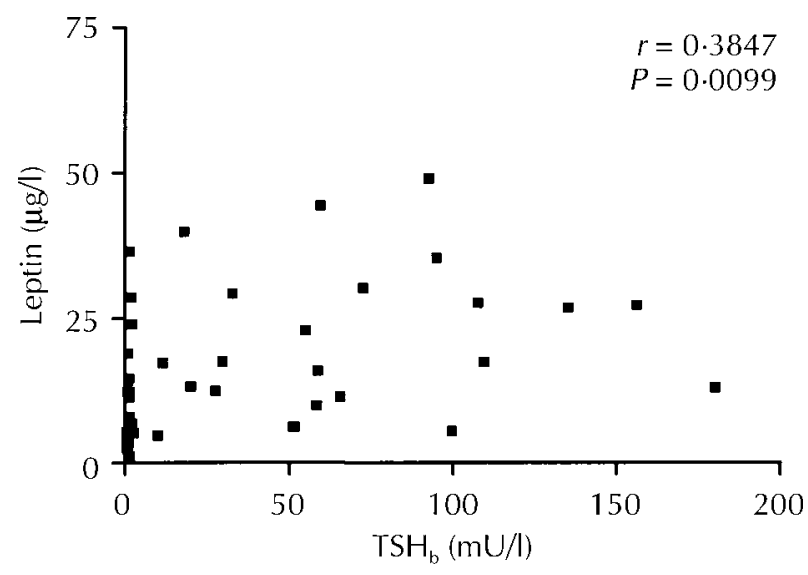

Figure 3 Correlation of serum leptin levels and $\mathrm{TSH}_{\mathrm{b}}$ in hypo- and euthyroid patients.

$27 \cdot 46 \pm 1.95 \mathrm{ng} / \mathrm{l}$ in the hyperthyroid, and $4.21 \pm$ $0.55 \mathrm{ng} / 1$ in the hypothyroid group. $\mathrm{FT}_{4}$ was $0.12 \pm$ $0.01 \mathrm{ng} / 1$ in euthyroid controls, $0.49 \pm 0.01 \mathrm{ng} / 1$ in the hyperthyroid, and $0.04 \pm 0.03 \mathrm{ng} / 1$ in the hypothyroid group (Table 1).

Leptin levels in hyperthyroid patients were not different from euthyroid controls. Leptin-IR in Graves' disease $(n=8, \quad 13 \cdot 0 \pm 2 \cdot 8 \mu \mathrm{g} / \mathrm{l})$ was similar to that in thyroid autonomy $(17 \cdot 0 \pm 5 \cdot 7 \mu \mathrm{g} / \mathrm{l}, n=11, P=0 \cdot 5826)$.

Serum leptin-IR in hypothyroid patients was significantly higher than in euthyroid controls $(21 \cdot 0 \pm 2 \cdot 7 \mu \mathrm{g} / 1$ vs $10 \cdot 8 \pm 2 \cdot 1 \mu \mathrm{g} / 1, \quad P=0 \cdot 0044$ ) (Fig. 4). When serum leptin of hypothyroid patients was compared with euthyroid controls of the same BMI (differences of $\mathrm{BMI} \leq 0 \cdot 5 \mathrm{~kg} / \mathrm{m}^{2}$ ) the difference was still significant $(P=0.0333$ by paired Student's $t$-test, $n=12)$. No difference was found in hypothyroid patients with thyroid carcinoma and in non-malignant hypothyroid disease $(20.6 \pm 3 \cdot 2 \mu \mathrm{g} / \mathrm{l}$ vs $21 \cdot 6 \pm 4 \cdot 7 \mu \mathrm{g} / \mathrm{l} ; P=0 \cdot 8574)$. The correlation coefficient for leptin-IR and $\mathrm{TSH}_{\mathrm{b}}$ concentrations in eu- and hypothyroid patients was $r=0.3847(P=0.0099$, $n=44)$ (Fig. 3). When eu- and hypothyroid patients were analysed separately it was $r=0.3463(P=0 \cdot 1240, n=21)$ in euthyroid controls and $r=0 \cdot 1547(P=0 \cdot 4810, n=23)$ in hypothyroid patients.

The mean serum leptin-IR in females was higher than in males (Table 1). This was true in euthyroid $(P=0 \cdot 0304)$, in hyperthyroid $(P=0.0967)$, and in hypothyroid patients $(P=0.0213)$. Leptin in hypothyroid females was significantly higher than in euthyroid females $(P=0 \cdot 0284)$, whereas the leptin-IR in hyperthyroid and euthyroid females did not differ $(P=0 \cdot 3954)$.

The overall correlation coefficient of the BMI and the serum leptin concentrations was $r=0.6678(P<0.0001$, $n=63) ; \quad$ and when analysed separately, $r=0.7340$ $(P=0.0002, \quad n=21)$ in euthyroid control subjects, $r=0 \cdot 6717(P=0 \cdot 0004, n=23)$ in hypothyroid, and $r=0 \cdot 6407$

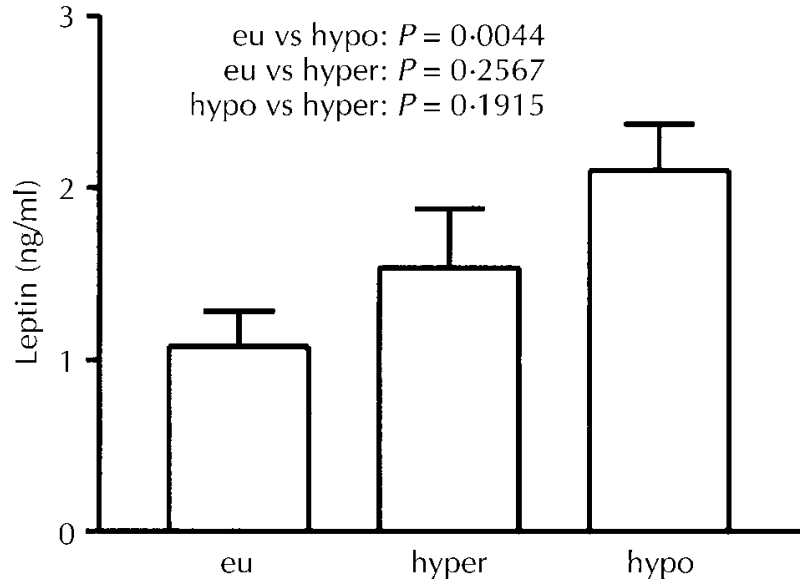

Figure 4 Mean serum leptin concentration in eu-, hyper-, and hypothyroid patients. Mean values \pm S.E.M.

$(P=0 \cdot 0031, n=19)$ in hyperthyroid patients. Mean serum insulin concentrations in euthyroid, in hyperthyroid and in hypothyroid patients were not different.

\section{Discussion}

Serum leptin levels are known to increase with the percentage of body fat and, to a lesser degree with the BMI. This might indicate insensitivity to endogenous leptin in obesity (Considine et al. 1996a,b). This was confirmed in our study. Since we showed a strong correlation of serum leptin and BMI, when hyper- or hypothyroid patients were analysed separately, thyroidal dysfunction does not attenuate weight related changes of leptin.

Higher leptin levels in women are in agreement with a recently published study demonstrating the involvement of sex hormones in the regulation of leptin synthesis (Saad et al. 1997). In addition, ob gene messenger RNA expression is increased in obese women compared with obese man (Lonnqvist et al. 1995).

Similar to the findings of Valcavi et al. (1997), an effect of hyperthyroidism on serum leptin was not detected. This is in agreement with the observation that administration of $\mathrm{T}_{3}$ to healthy volunteers did not alter circulating leptin, although cardiovascular and metabolic effects were present (Mantzoros et al. 1997).

The increased leptin levels in hypothyroidism are not due to a direct effect of thyreostatic medication since leptin was increased both in drug-induced hypothyroidism and in autoimmune disease. In contrast to our finding, Valcavi et al. (1997) described a decrease of the serum leptin-IR levels in primary hypothyroidism. There is no obvious explanation for the discrepancy, although the TSH levels in hypothyroidism were two-fold lower and 
the BMI was higher in our study. The differences cannot be attributed to crossreactivity of the antibody since we demonstrated that the antibody used did not bind thyroid hormones or TSH or insulin. Gel chromatographic runs of serum samples indicated that our antibody detected the complete and intact protein.

In our study we could exclude that changes in leptin were secondary to altered insulin levels, since mean insulin was not different in eu-, hyper-, and hypothyroid patients. Insulin is known to stimulate $o b$ gene expression and to increase serum leptin concentration in non-insulindependent diabetes mellitus (NIDDM) (Cusin et al. 1995). In non-obese NIDDM patients, leptin synthesis is resistant to the acute effect of insulin, whereas testosterone may contribute to the regulation of leptin synthesis in these patients (Tuominen et al. 1997, Widaja et al. 1997).

The significant increase of leptin in hypothyroidism cannot be explained by differences in body weight because leptin levels remained significantly increased when compared with controls with an identical BMI. This might indicate that elevation of the serum leptin level does not merely reflect changes in body weight secondary to hypothyroidism, but might be increased to overcome the gain of body weight caused by hypothyroidism.

\section{References}

Campfield LA, Smith FJ, Guisez Y, Devos R \& Burn P 1995 Recombinant mouse ob protein: evidence for a peripheral signal linking adiposity and central neural networks. Science 269 546-549.

Clement K, Garner C, Hager J, Philippi A, LeDuc C, Carey A, Harris TJ, Jury C, Cardon LR, Basdevant A, Demenais F, Guy-Grand B, North M \& Froguel P 1996 Indication for a linkage of the human ob gene region with extreme obesity. Diabetes $\mathbf{4 5 5}$ 687-690.

Considine RV, Sinha MK, Heiman ML, Kriauciunas A, Stephens TW, Nyce MR, Ohannesian J, Marco CC, McKee LJ, Bauer TL \& Caro JF 1996a Serum immunoreactive-leptin concentrations in normal-weight and obese humans. New England Journal of Medicine 334 292-295.

Considine RV, Considine EL, Williams CJ, Hyde TM \& Caro JF $1996 b$ The hypothalamic leptin receptor in humans: identification of incidental sequence polymorphisms and absence of the $\mathrm{db} / \mathrm{db}$ mouse and fa/fa mutations. Diabetes 45 992-994.

Cusin I, Sainbury A, Doyle P, Rohner-Jeanrenaud F \& Jeanrenaud B 1995 The ob gene and insulin. A relationship leading to clues to the understanding of obesity. Diabetes 44 1467-1470.

Ingbar SH 1985 The thyroid gland. In Textbook of Endocrinology, pp 975-1170. Eds JD Wilson \& DW Foster. Philadelphia: Saunders.

Lonnqvist F, Arner P, Nordfors L \& Schalling M 1995 Overexpression of the obese (ob) gene in adipose tissue of human obese subjects. Nature Medicine 1 950-953.
Maffei M, Stoffel M, Barone M, Moon B, Dammerman M, Ravussin E, Bogardus C, Ludwig DS, Flier JS, Talley M, Auerbach S \& Friedman JM 1996 Absence of mutations in the human ob gene in obese/diabetic subjects. Diabetes 455 679-682.

Mantzoros CS, Rosen HN, Greenspan SL, Flier JS \& Moses AC 1997 Short-term hyperthyroidism has no effect on leptin levels in man. Journal of Clinical Endocrinology and Metabolism 82 497-499.

Niki T, Mori H, Tamori Y, Kishimoto-Hashirmoto M, Ueno H, Araki S, Masugi J, Sawant N, Majithia HR, Rais N, Hashiramoto M, Tanigucchi H \& Kasuga M 1996 Human obese gene: molecular screening in Japanese and Asian Indian NIDDM patients associated with obesity. Diabetes 455 675-678.

Pelleymounter MA, Cullen MJ, Baker MB, Hecht R, Winters D, Boone T \& Collins F 1995 Effects of the obese gene product on body weight regulation in ob/ob mice. Science 269 540-543.

Reed DR, Ding Y, Xu W, Cather C, Green ED \& Price RA 1996 Extreme obesity may be linked to markers flanking the human ob gene. Diabetes 455 691-694.

Rohner-Jeanrenaud F \& Jeanrenaud B 1996 Obesity, leptin, and the brain. New England Journal of Medicine 334 324-325.

Rohner-Jeanrenaud F, Cusin I, Sainsbury A, Zakrewska KE \& Jeanrenaud B 1996 The loop system between neuropeptide Y and leptin in normal and obese rodents. Hormone and Metabolic Research 28 642-648.

Saad MF, Damani S, Gingerich RL, Riad-Gabriel MG, Khan A, Boyadjian R, Jinagouda SD, El-Tawil K, Rude RK \& Kamdar V 1997 Sexual dimorphism in plasma leptin concentration. Journal of Clinical Endocrinology and Metabolism 82 579-584.

Stephens TW, Basinski M, Bristow PK, Bue-Valleskey JM, Burgett SG, Craft L, Hale J, Hoffmann J, Hsiung HM, Kriauciunas A, MacKellar W, Rosteck PR, Schoner B, Smith D, Tinsley FC, Zhang XY \& Heiman M 1995 The role of neuropeptide Y in the antiobesity action of the obese gene product. Nature 377 530-532.

Tuominen JA, Ebeling P, Stenman UH, Heiman ML, Stephens TW \& Koivisto VA 1997 Leptin synthesis is resistant to the acute effects of insulin in insulin-dependent diabetes mellitus patients. Journal of Clinical Endocrinology and Metabolism 82 381-382.

Valcavi R, Zini M, Peino R, Casanueva FF \& Dieguez C 1997 Influence of thyroid status on serum immunoreactive leptin levels. Journal of Clinical Endocrinology and Metabolism 82 1632-1634.

Wang Q, Bing C, Al-Barazanji K, Mossakowaska DE, Wang XM, McBay DL, Neville WA, Taddayon M, Pickavance L, Dryden S, Thomas MEA, McHale MT, Gloyer IS, Wilson S, Buckingham R, Arch JRS, Trayhurn P \& Williams G 1997 Interactions between leptin and hypothalamic neuropeptide $\mathrm{Y}$ neurons in the control of food intake and energy homeostasis in the rat. Diabetes 46 335-341.

Widaja A, Stratton IM, Horn R, Holmann RR, Turner R \& Brabant G 1997 UKPDS 20: Plasma leptin, obesity, and plasma insulin in type 2 diabetic subjects. Journal of Clinical Endocrinology and Metabolism 82 654-657.

Zhang Y, Proenca R, Maffei M, Barone M, Leopold L \& Friedman JM 1994 Positional cloning of the mouse obese gene and its human homologue. Nature 372 425-432.

Received 29 May 1997

Revised manuscript received 8 October 1997

Accepted 31 October 1997 